\title{
Bibliometric trending analysis of complications related to facial non-surgical aesthetic procedures: a retrospective study
}

\author{
Analiza trendów bibliometrycznych powikłań związanych \\ z niechirurgicznymi zabiegami estetycznymi twarzy: \\ badanie retrospektywne
}

\section{Ricardo Grillo}

Department of Oral surgery, Institute and Reaserch Centre, São Leopoldo Mandic, Brazil

KEY WORDS:

aging face, bibliometrics, citation analysis, botulinum toxins, dermal fillers, facial rejuvenation

\section{Summary}

Aim of the study. This work aims to provide a bibliometric analysis of the publication trends on complications related to non-surgical aesthetic procedures on the face over the past 20 years.

Methods. A bibliographic search was carried out in Pubmed and Dimensions on the same date to avoid risk of bias, and included three different aesthetic procedures: botulinum toxin injections for aesthetic purposes, dermal fillers and suspension threads. The number of citations, the altmetric attention score (AAS), and the topics were analyzed with Microsoft Excel and XLSTAT. The graphic representation of the keywords was created with VOSviewer. Statistical analyses have taken into account a 95\% confidence interval.

Results. Complications related to facial nonsurgical aesthetic procedures are increasing, but complications related to dermal fillers are in a more robust upward trend $(p<0.05)$. Open access articles have a higher chance of being mentioned than paid articles. Having an appropriate keyword is crucial to the dissemination of articles.

Conclusions. Bibliometrics and altmetrics are valuable tools for researchers, editors, students
HASŁA INDEKSOWE:

starzenie się twarzy, bibliometria, analiza cytowań, toksyny botulinowe, wypełniacze skóry, odmładzanie twarzy

\section{Streszczenie}

Cel. Celem pracy jest przedstawienie bibliometrycznej analizy trendów publikacyjnych dotyczacych powiklań zwiazanych z niechirurgicznymi zabiegami estetycznymi na twarzy w ciagu ostatnich 20 lat.

Metody. Przeszukanie bibliograficzne zostało przeprowadzone $w$ Pubmed i Dimensions $w$ tym samym dniu, aby uniknać ryzyka błędu systematycznego i obejmowato trzy różne procedury estetyczne: zastrzyki toksyny botulinowej w celach estetycznych, wypetniacze skórne i nici do zawieszania. Liczba cytowań, alternatywny wskaźnik uwagi (AAS) $i$ tematy zostały przeanalizowane za pomoca Microsoft Excel i XLSTAT. Graficzna reprezentacja stów kluczowych została stworzona za pomoca VOSviewer. Analizy statystyczne uwzględniaty 95\% przedział ufności.

Wyniki. Rośnie liczba powikłań związanych z niechirurgicznymi zabiegami estetycznymi twa$r z y$, ale powiktania zwiąane $z$ wypetniaczami skórnymi wykazuja silniejszy trend wzrostowy $(p<0,05)$. Artykuly o otwartym dostepie maja większa szansę na wzmiankę niż artykuty ptatne. Posiadanie odpowiedniego stowa kluczowego ma 
or academics, saving those interested a lot of time and effort. fundamentalne znaczenie dla rozpowszechniania artykułów.

Wnioski. Bibliometria i analiza danych sa cennymi narzędziami dla badaczy, redaktorów, studentów lub naukowców, oszczędzając zainteresowanym dużo czasu i wysitku.

Epidemiology (STROBE) Statement. ${ }^{4}$ This paper attempted to follow the principles of the Leiden Manifesto, ${ }^{5}$ with particular attention to transparency, avoidance of false precision and allowing data to be verified.

\section{Search strategy}

A literature search was carried out on the PubmedplatformfromJanuary2001 toDecember 2020. A research was conducted using the terms which included three different procedures: botulinum toxin injections for aesthetic purposes - ((botulinum OR botulinum) AND toxin) AND (wrinkle OR gummy OR esthetics OR lift) AND (complication OR adverse), dermal fillers - ((dermal filler) NOT fat) AND (complication OR adverse), and suspension threads - (suspension OR lifting OR face OR facial) AND (thread) AND (complication OR adverse). No language restrictions, journal impact factor, or methodology selections were applied. As a review, this article is exempt from approval by the institutional review board.

\section{Data extraction and Bibliometric Parameters}

Articles were identified by searching Pubmed. The researcher designed a table in Microsoft Office Excel, and each variable was hand-searched to identify the subject area, year of publication and Altmetric Attention Score (AAS), using the Dimensions app. In order to be included in this study sample, publications had to present a complication or side effect in connection with at least one of the described above aesthetic procedures (botulinum toxin, 
dermal fillers and suspension threads), without language restriction, in the last 20 years.

\section{Methodological design and data analysis}

A bibliometric analysis included published articles on complications associated with facial non-surgical aesthetic procedures with the aim of assessing publication trends over the past 20 years. This bibliometric analysis was done to compare outcomes and complications or side effects. In addition, a correlation between open articles and the number of citations and mentions was examined. Tables were created with Microsoft Excel. Statistical analysis by Microsoft Excel and XLSTAT. The free software VOS-Viewer (Leiden University, The Netherlands) was used to create a graphical representation of some critical elements, a visual form of bibliometric analysis. Chisquare test, Mann-Kendall test and KruskalWallis test were performed in Microsoft Excel and XLSTAT $(\mathrm{p}<0.05)$.

\section{Results}

The search yielded a total of 3,978 publications on facial aesthetic procedures but only 1,803 articles with complication or side effects in the last 20 years were evaluated. The number of articles on complications from certain procedures included 589 on botulinum toxin (32.66\%), 1,011 on dermal fillers (56.07\%) and 203 on suspension threads $(11.25 \%)$. It can be observed that the publication productivity on complications from facial non-surgical

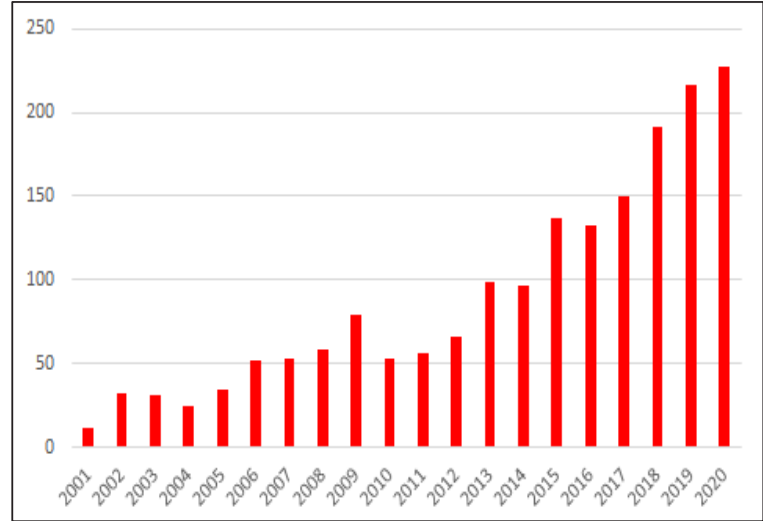

Fig. 1. Year distribution of the number of publications about complications concerning facial non-surgical aesthetic procedures.

aesthetic procedures has increased compared to 2013 (Fig. 1). Almost $70 \%$ of the total publications were published from 2013 to 2020. The year of 2020 was the most productive one with 227 articles.

A Mann-Kendall test gave positive values for Sen's slope (trend) and Kendall's tau, ordinal association between two variables (Table 1). This demonstrates that three procedures have an increasing number of publications related to complications - an upward trend. Nevertheless, dermal filler articles are showing a more robust upward trend (Fig. 2). In addition, a statistically significant $p$-value was equal to three procedures $(\mathrm{p}<0.0001)$.

A Kruskal-Wallis test was carried out to examine the number of publications on three aesthetic procedures. A significant difference $\left(\chi^{2}=19.566, \mathrm{p}<0.0001, \mathrm{df}=2\right)$ was found among

Ta ble 1. Complications trend acc. to Mann-Kendall test

\begin{tabular}{|l|c|c|c|}
\hline \multicolumn{1}{|c|}{ Procedure } & Kendall's tau & p-value & Sen's slope \\
\hline Botulinum toxin & 0.606 & 0.000 & 1.458 \\
\hline Dermal filler & 0.913 & $<0.0001$ & 7.243 \\
\hline Suspension threads & 0.576 & 0.001 & 0.637 \\
\hline
\end{tabular}




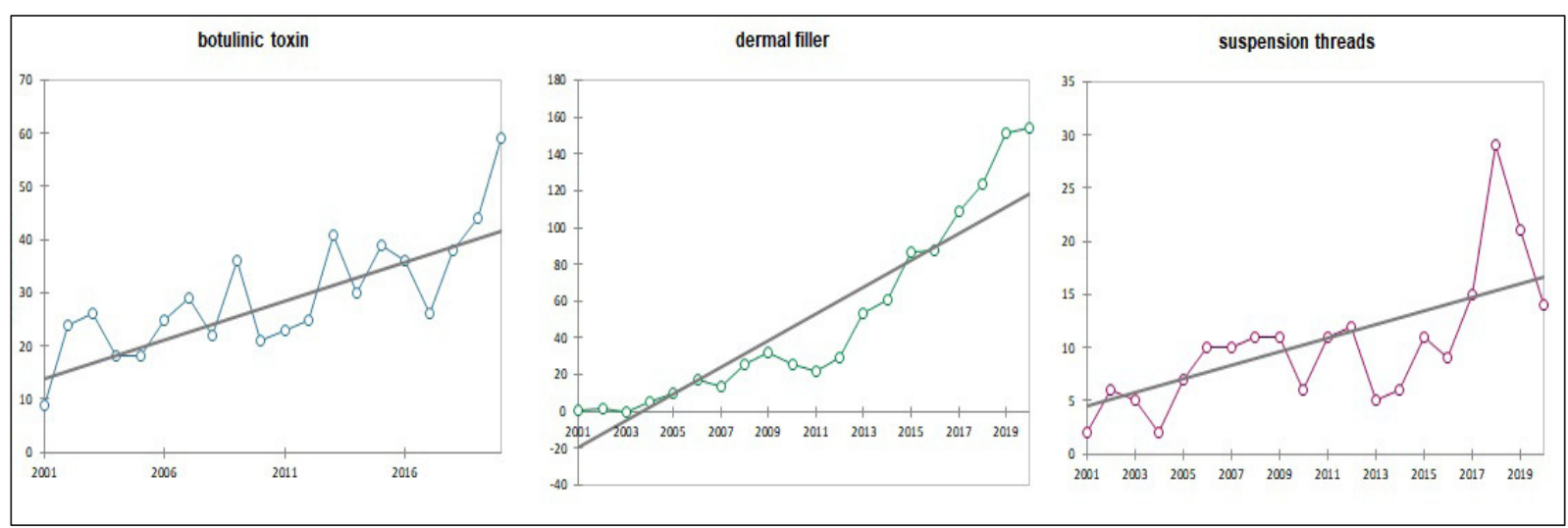

Fig. 2. Trend of botulinum toxin (blue), dermal fillers (green) and suspension threads (purple). Performed through Microsoft Excel and XLSTAT.

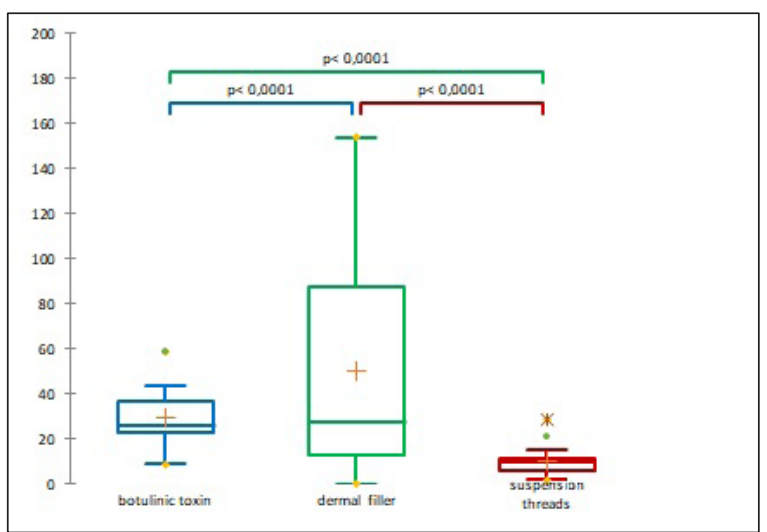

Fig. 3. Box plot graph difference on the number of publications among three procedures

botulinum toxin, dermal fillers and suspension threads complications (Fig. 3).

With regard to accessibility, the open-access articles (155) were mentioned in $29.30 \%$ of the articles (529). Open access articles have more chances of being mentioned, $\chi^{2}(1, \mathrm{~N}=1,803)$ $=9.8932, \mathrm{p}=0.001659$.

The most common MeSH keywords were "skin aging", "cosmetic techniques", "middle aged", "botulinum toxins, type a", and "dermal fillers". Alastair J. Carruthers from the University of British Columbia, Canada, is the most frequently occurring author keyword. Figures 4 and 5 show a graphic representation of keywords and authors in a network

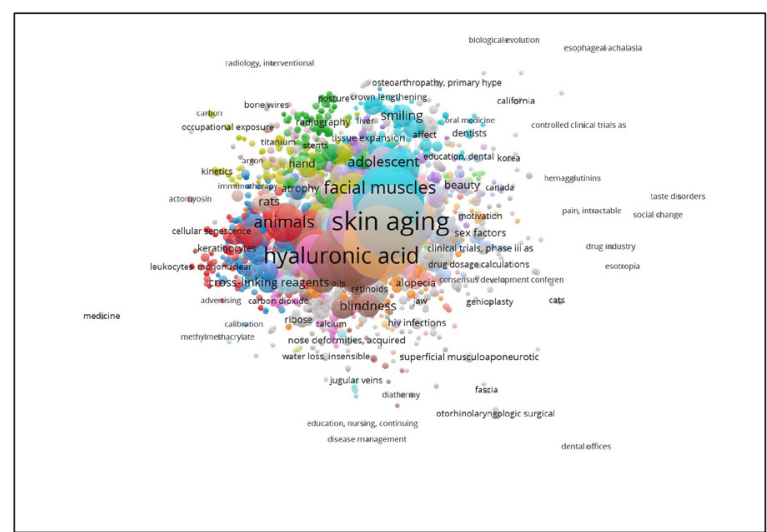

Fig. 4. A network visualization of MeSH keywords performed with VOSviewer.

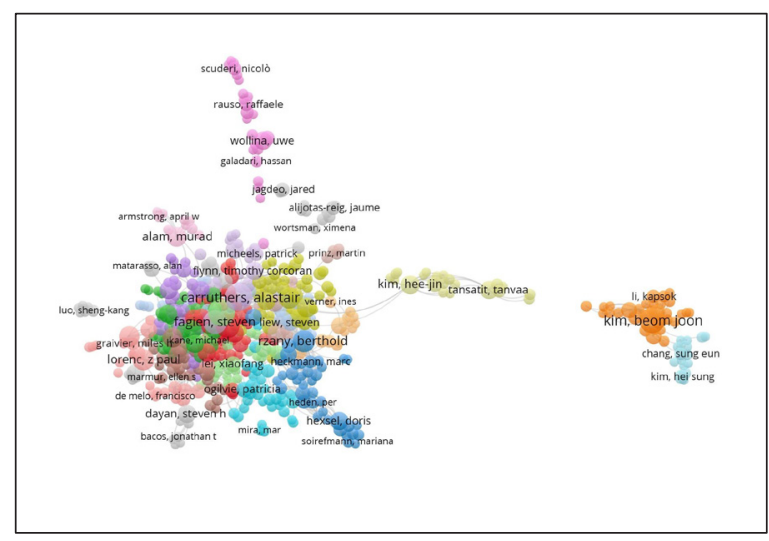

Fig. 5. A network visualization of authors'occurrence performed with VOSviewer.

visualization that was created with the free VOSviewer software. 


\section{Discussion}

This aim of this study was to carry out a bibliometric analysis of aesthetic nonsurgical facial complications. Graphical data visualization using bibliometric software and statistical tests $(\mathrm{p}<0.05)$ were carried out to make the information easier to assimilate. Bibliometric analysis allows researchers and readers to see the evolution of research in a particular area over time and to get a better understanding of that area and some of the possible errors. ${ }^{6}$

Bibliometrics and altmetrics comprise statistical methods and tools for the quantitative analysis of scientific literature that changes over time. ${ }^{7}$ Both methods have their advantages. While bibliometrics takes a more traditional approach, altmetrics provides a complementary measure of scientific articles, through webbased citations. ${ }^{8}$ Combining these methods could result in a high quality bibliographic search, useful in many ways, such as setting up a class, writing a scientific paper, or mapping a publication trend, even if the bibliometrics is not precise enough. ${ }^{5}$

An effective way to evaluate publishing trends is to assess MeSH (Medical Subject Headings) descriptors, relevant words used by the author to better describe the topic of the article. ${ }^{9}$ One interesting finding of this study is keywords significance, crucial to determine the subject content of an article and describe the content through a controlled vocabulary. ${ }^{10}$ The purpose of controlled vocabulary indexing is to facilitate the search and thereby increase the precision, sensitivity and efficiency of a bibliographic search. ${ }^{11}$ Network analysis of keywords through a graphical visualization is useful in choosing an appropriate title and keywords, an effective method for wider dissemination as a search for a specific keyword will result in a wide variety of specialty journals. ${ }^{12}$

The main finding of this study was that there is an increasing interest in articles about complications in facial non-surgical aesthetic procedures, especially on dermal fillers. An article on dermal fillers complications has a fivefold chance of being read, cited and mentioned than those on botulinum toxin or suspension threads. This information is useful to researchers and improves the quality of study, ${ }^{7}$ hence the quality of scientific critical information as the number on this topic is on an upward trend.

Although there are disparities between the most cited and the most mentioned articles, ${ }^{13}$ open access articles have a higher chance of being mentioned. The same correlation was not examined for the number of citations and open access.

\section{Conclusions}

Bibliometric and altmetric analyses, while inaccurate, are very useful to researchers, academics, and students. Both can facilitate studies, research or publications and save time and effort with the required bibliographical references. Choosing a suitable keyword is a critical step towards extensive dissemination. The publication of dermal fillers complications shows an upward trend, which is helpful information for researchers and editors. Future studies are needed as the science is very dynamic and this list needs to be periodically updated.

\section{References}

1. Lehane DJ, Black CS: Can altmetrics predict future citation counts in critical care medicine publications? J Intensive Care Soc 2021; 22(1): 60-66.

2. Chellappandi $P$, Vijayakumar CS: Bibliometrics, Scientometrics, Webometrics/ Cybermetrics, Informetrics and Altmetrics An Emerging Field in Library and Information Science Research. Int J Educ 2018; 7(1): 5-8. 
3. Kim JE, Kim Y, Park KM, Yoon DY, Bae $J S$ : Top 100 Publications as Measured by Altmetrics in the Field of Central Nervous System Inflammatory Demyelinating Disease. Biomed Res Int 2019; 2019.

4. Vandenbroucke JP, von Elm E, Altman DG, Gøtzsche PC, Mulrow CD, Pocock SJ, et al.: Strengthening the Reporting of Observational Studies in Epidemiology (STROBE): Explanation and elaboration. Int J Surg 2014; 12(12): 1500-1524.

5. Hicks D, Wouters P, Waltman L, De Rijcke S, Rafols I: Bibliometrics: The Leiden Manifesto for research metrics. Vol. 520, Nature. 2015. p. 429-431.

6. Martelli AJ, Martelli RAM, Martelli DRB, das Neves LT, Martelli Junior H: The 100 mostcited papers in oral medicine and pathology. Braz Oral Res 2021; 35: 1-14.

7. Chaudhry K, Bali RK, Kaur A, Tiwari RVC, Patnana AK: Level of Evidence Analysis in Journal of Maxillofacial Oral Surgery: A Twelve-Year Bibliometric Analysis of 1300 Publications (2009-2020). J Maxillofac Oral Surg 2021; 1-9.

8. Moon JY, Yun EJ, Yoon DY, Seo YL, Cho $Y K$, Lim KJ, et al.: Analysis of the altmetric top 100 articles with the highest altmetric attention scores in medical imaging journals. Jpn J Radiol 2020; 38(7): 630-635.

9. Huang X, Liu X, Shang Y, Qiao F, Chen
G. Current Trends in Research on Bone Regeneration: A Bibliometric Analysis. Biomed Res Int 2020; 2020.

10. USA: US National Library of Medicine National Institute of Health. Principles of MEDLINE Subject Indexing [Internet]. U.S. National Library of Medicine; [cited 2021 May 10]. Available from: https:// www.nlm.nih.gov/bsd/disted/meshtutorial/ principlesofmedlinesubjectindexing/ principles/index.html

11. Baumann N: How to use the medical subject headings (MeSH). Int J Clin Pract 2016; 70(2): 171-174.

12. Mondal H, Mondal S, Mondal S: How to choose title and keywords for manuscript according to medical subject headings. Indian J Vasc Endovasc Surg 2018; 5(3): 141.

13. Hong JH, Yoon DY, Lim KJ, Moon JY, Baek $S$, Seo YL, et al.: Characteristics of the Most Cited, Most Downloaded, and Most Mentioned Articles in General Medical Journals: A Comparative Bibliometric Analysis. Healthc (Basel, Switzerland). 2020; 8(4): 492.

Zaakceptowano do druku: 8.07.2021 r.

Adres autora: Prof. Ricardo, Grillo Department of Oral Surgery, São Leopoldo Mandic, 13045-755 Campinas, SP, Brazil

(c) Zarząd Główny PTS 2021. 